\title{
Myocardial fibrosis quantified by the extracellular extravascular volume fraction is associated with the left ventricular sphericity index and the left atrial volume index
}

\author{
Diego Moguillansky ${ }^{1,2^{*}}$, Timothy C Wong ${ }^{1}$, Christopher G Meier ${ }^{1}$, Stephen M Testa', David Testa', \\ William J Ceyrolles ${ }^{1}$, Kayla Piehler ${ }^{1}$, Peter Kellman ${ }^{3}$, Erik B Schelbert ${ }^{1}$
}

From 15th Annual SCMR Scientific Sessions

Orlando, FL, USA. 2-5 February 2012

\section{Summary}

The objective of this study is to test the hypothesis that quantitative measures of myocardial fibrosis such as the myocardial extravascular extracellular volume fraction (Ve) are associated with markers of adverse cardiac remodeling such as the left atrial volume index (LAVi) and left ventricular sphericity index $(\mathrm{Si})$.

\section{Background}

LAVi and $\mathrm{Si}$ are intermediate phenotypes that precede adverse outcomes. Myocardial fibrosis is quantifiable with contemporary CMR techniques, is treatable, and may represent a therapeutic target when these intermediate phenotypes are present.

\section{Methods}

We measured myocardial Ve in 267 individuals referred for CMR without confounders such as myocardial infarction, where $\mathrm{Ve}=[\lambda \rho(1-\mathrm{Hct})-\mathrm{Vp}]$; the specific density of myocardial tissue, $\rho=1.05$; the myocardial plasma volume fraction, $\mathrm{Vp}=0.045$, and $\lambda=\Delta \mathrm{R} 1$ myocardium/ $\Delta$ R1blood. T1 was measured with an ECG-gated MOLLI sequence acquired before and 20 minutes after a gadolinium contrast bolus $(0.2 \mathrm{mmol} / \mathrm{kg})$. LAVi and $\mathrm{Si}$ were measured from standard SSFP cine images: LAVi = $[8 / 3 \pi[(\mathrm{A} 1)(\mathrm{A} 2) / \mathrm{L}]$ where $\mathrm{A} 1$ and $\mathrm{A} 2$ are LA areas from end-systolic 2-chamber and 4-chamber views, $L$ represents the shortest anteroposterior LA dimension from

${ }^{1}$ Cardiovascular Disease, University of Pittsburgh Medical Center, Pittsburgh, PA, USA

Full list of author information is available at the end of the article either view, and $\mathrm{Si}=\mathrm{EDV} /\left[\mathrm{LAX}^{\wedge} 3 \pi / 6\right)$, where $\mathrm{EDV}$ is the end-diastolic volume measured from short axis stacks and $\mathrm{LAX}^{\wedge} 3$ is the cube of the long axis diastolic dimension from a 4 chamber view. Multivariable linear regression models quantified the association of Ve with LAVi and $\mathrm{Si}$, adjusting for key characteristics identified by stepwise selection.

\section{Results}

Ve was associated with LAVi ( $\mathrm{t}$ value $4.5, \mathrm{p}<0.001$ ), and this association remained after adjusting for age, ejection fraction, EDV index, and left ventricular mass index ( $t$ value $2.8, \mathrm{p}=0.005)$. Ve was also associated with $\mathrm{Si}(\mathrm{t}$ value $5.6, \mathrm{p}<0.001)$, and this association remained after adjusting for age, gender, EDV index, body mass index, and left ventricular mass index ( $\mathrm{t}$ value $2.18, \mathrm{p}=0.036$ ).

\section{Conclusions}

$\mathrm{Ve}$ is associated with key intermediate phenotypes that indicate adverse cardiac remodeling such as LAVi and Si.

\section{Funding}

Dr Erik Schelbert is supported by a University of Pittsburgh Foundation Grant, and by an American Heart Association Scientist Development Grant (09SDG 2180083).

\section{Author details}

${ }^{1}$ Cardiovascular Disease, University of Pittsburgh Medical Center, Pittsburgh, PA, USA. ${ }^{2}$ Congenital Heart Center, University of Florida, Gainesville, FL, USA. 
Published: 1 February 2012

doi:10.1186/1532-429X-14-S1-P294

Cite this article as: Moguillansky et al: Myocardial fibrosis quantified by the extracellular extravascular volume fraction is associated with the left ventricular sphericity index and the left atrial volume index. Journal of Cardiovascular Magnetic Resonance 2012 14(Suppl 1):P294.

Submit your next manuscript to BioMed Central and take full advantage of:

- Convenient online submission

- Thorough peer review

- No space constraints or color figure charges

- Immediate publication on acceptance

- Inclusion in PubMed, CAS, Scopus and Google Scholar

- Research which is freely available for redistribution

Submit your manuscript at www.biomedcentral.com/submit
C) Biomed Central 